\title{
Molecular and morphological characterization of Contracaecum pelagicum (Nematoda) parasitizing Spheniscus magellanicus (Chordata) from Brazilian waters
}

\author{
Caracterização molecular e morfológica de Contracaecum pelagicum (Nematoda) \\ parasito de Spheniscus magellanicus (Chordata) em águas brasileiras \\ Juliana Novo Borges ${ }^{1,2} ;$ Helena Lúcia Carneiro Santos ${ }^{1}$; Martha Lima Brandão ${ }^{3}$; \\ Everton Gustavo Nunes dos Santos ${ }^{1,3}$; Daniele Ferreira de Miranda ${ }^{1}$; \\ Daniel de Almeida Balthazar ${ }^{4}$; José Luis Luque ; Cláudia Portes Santos ${ }^{1 *}$
}

\begin{abstract}
${ }^{1}$ Laboratório de Avaliação e Promoção da Saúde Ambiental - LAPSA, Instituto Oswaldo Cruz - IOC, Rio de Janeiro, RJ, Brasil
${ }^{2}$ Curso de Pós-graduaçáo em Biodiversidade e Saúde, Instituto Oswaldo Cruz - IOC, Fundação Oswaldo Cruz - Fiocruz,

Rio de Janeiro, RJ, Brasil

${ }^{3}$ Curso de Pós-graduação em Parasitologia Veterinária, Universidade Federal Rural do Rio de Janeiro - UFRRJ, Seropédica, RJ, Brasil

${ }^{4}$ Fundação Jardim Zoológico da Cidade do Rio de Janeiro, RJ, Brasil

${ }^{5}$ Departamento de Parasitologia Animal, Universidade Federal Rural do Rio de Janeiro - UFRRJ, Seropédica, RJ, Brasil
\end{abstract}

Received October 15, 2013

Accepted February 5, 2014

\begin{abstract}
Three new sequences of Mitochondrial cytochrome c-oxidase subunit 2 (mtDNA cox-2) from C. pelagicum parasite of Spheniscus magellanicus, the Magelanicus penguin, were determined from Brazilian waters. The sequences presented 99 and 98\% of similarity with C. pelagicum sequences from Argentina, deposited on GenBank for the same genetic region and with a strong statistical support inferred from the phylogenetic tree. The morphological and ultrastructural studies that were carried out confirmed the genetic analysis.
\end{abstract}

Keywords: Anisakidae, penguin, Rio de Janeiro.

\section{Resumo}

Foram determinadas três novas sequências da regiáo do Citocromo c-oxidase da subunidade II do DNA mitocondrial (cox-2 mtDNA) de Contracaecum pelagicum, parasito de Spheniscus magellanicus, pinguim Magalháes, de águas brasileiras. As sequências apresentaram 99 e $98 \%$ de similaridade com sequências de C. pelagicum da Argentina depositadas no GenBank da mesma região genética com forte suporte estatístico inferido pela arvore filogenética. Estudos morfológicos e ultraestruturais realizados confirmaram a identidade genética.

Palavras-chave: Anisakidae, pinguim, Rio de Janeiro.

\section{Introduction}

Adult Contracaecum pelagicum, Johnston and Mawson, 1942, is an Anisakidae nematode known for parasitizing marine mammals and piscivorous birds. The Contracaecum sp. larvae can be found in several invertebrates and in fish that act as intermediate hosts (ANDERSON, 2000).

The species was first described from albatrosses from Australia and, since then the species was reported in South America from Thalassarche melanophris (=Diomedea melanophris (Temminck, 1828), the South American penguin, Spheniscus magellanicus

\footnotetext{
*Corresponding author: Cláudia Portes Santos

Departamento de Parasitologia Animal, Universidade Federal Rural do Rio de Janeiro - UFRRJ, BR 465, Km 7, CEP 23890-000, Seropédica, RJ, Brasil e-mail: cpsantos@ioc.fiocruz.br
}

(Forster, 1781), Spheniscus humboldti Meyen, 1834 and Sula leucogaster Boddaert, 1783 (LENT; FREITAS, 1948; SANTOS, 1984; MANN, 1992; SILVA et al., 2005; GARBIN et al., 2007; GONZÁLEZ-ACUÑA et al., 2008; EDERLI et al., 2009; DIAZ et al., 2010; PRADO et al., 2011; YÁÑEZ et al., 2012; REZENDE et al., 2013; CAMPOS et al., 2013).

Few genetic studies of $C$. pelagicum were performed by Mattiucci et al. (2008) and Garbin et al. $(2011,2013)$ from the intermediate host, the anchovy Engraulis anchoita Hubbs and Marini, 1935, and from the definitive hosts S. magellanicus and Phalacrocorax atriceps King PP, 1828 from Argentina. However, there are no molecular data of Contracaecum species recovered from penguins found in the Brazilian coast. 
Magellan penguins are opportunistic feeders and, in the southern hemisphere during winter time, they may travel along the currents foraging for prey far apart from their original area, the Antarctica and Argentinean coast, reaching the Brazilian southeast and northeast coasts (SERAFINI et al., 2010). In the Brazilian coast, the Magellan penguins are commonly found ill or dead, stranded on the coast (GARCÍA BORBOROGLU et al., 2010). This paper deals with the morphological study and Mitochondrial cytochrome c-oxidase subunit 2 (mtDNA cox-2) sequence analysis of $C$. pelagicum, obtained from penguins found in Rio de Janeiro, Brazil.

\section{Materials and Methods}

The gastrointestinal tract of two Magelanic penguins was donated by Riozoo foundation at Rio de Janeiro, in December of 2012 and transported in $70 \%$ alcohol to the laboratory. One penguin found stranded on the beach was transported to the Laboratory of Parasitology of the Universidade Federal Rural do Rio de Janeiro for examination. A total of 12 adult nematodes (three males and nine females) were collected in the intestine of the penguins, and five were cut into three pieces: the anterior and posterior parts were mounted in glycerine jelly for morphological identification, and the middle parts were prepared for genetic studies. Measurements are given in micrometers $(\mu \mathrm{m})$ unless otherwise stated, and the means are stated in parentheses. Specimens are deposited in the Helminthological collection of the Instituto Oswaldo Cruz (CHIOC), Rio de Janeiro, Brazil (n. 35913).

Some specimens were prepared for scanning electron microscopy by dehydrating through a graded ethanol series. The specimens were then transferred to 50:50 100\% ethanol: hexamethyldisilazane, followed by a change of $100 \%$ hexamethyldisilazane and air dried overnight. Mounted specimens were sputter-coated with gold and examined using a Jeol JSM-6791F microscope at an accelerating voltage of $15 \mathrm{kV}$.

Genomic DNA was extracted using a ChargeSwitch gDNA Mini Tissue Kit (Invitrogen, Carlsbad, CA, USA) and in order to amplify gene fragments of Contracaecum; the primers 211F/210R for mtDNA cox-2 (NADLER; HUDSPETH, 2000) were used in PCR reactions following Borges et al. (2012). Amplified PCR products were purified with Wizard $^{\circledR}$ SV gel and PCR clean up system kit (Promega, Madison, USA), and sequenced using the same primer set. DNA cycle-sequencing reactions were performed using BigDye v.3.1 chemistry (Applied Biosystems, Foster City, CA, USA) in the ABI Prism 3100 sequence analyzer. Sequences were edited in DNASTAR SeqMan (DNASTAR, Inc., Madison, WI) and compared for similarities with sequences from GenBank, using BLAST 2.0 ("Basic Local Alignment Search Tool”) (ALTSCHUL et al., 1990) (Table 1). Alignments were performed by CLUSTAL W algorithm (THOMPSON et al., 1994), and the probability of substitutions plus phylogenetic trees were inferred by using the MEGA 5.0 software (TAMURA et al., 2011). The Hasegawa-Kishino-Yano model (HKY) was selected using the jModelTest program (POSADA, 2008), and the Maximum Likelihood method was used to construct trees (FELSENSTEIN, 1981) that were resampled by 1000 bootstrap replicates.

\section{Results}

Contracaecum pelagicum was identified based on measurements and morphological observations by light and scanning electron microscopy, in addition to a genetic analysis.

Measurements of males, based on two specimens. Body 40-45 mm long, 0.97-1.16 wide. Anterior region with one dorsal and two ventrolateral lips. Interlabia present. Nerve ring $0.49-0.50$ and deirids 0.92-1.00 from anterior end. Oesophagus 2.43-3.82. Ventricular appendix 0.85. Intestinal cecum 1.90-2.69. Right spicule 4.10-4.33 and left 4.00-4.13. Precloacal papillae 23-25 and post-cloacal papillae 7. Cloaca/end of body 0.20-0.24.

Measurements of females, based on four specimens. Body 46-62 (58) $\mathrm{mm}$ long and width 1.20-1.50 (1.31). Anterior region with one dorsal and two ventrolateral lips. Interlabia present. Nerve ring 0.48-0.70 (0.60) and deirids 0.71-1.14 (0.91). Oesophagus 3.40-4.15 (4.11). Ventricular appendix 0-70-0.79 (0.74). Intestinal cecum 2.70-3.05 (2.88). Cloaca/end of body 0.45-0.47 (0.43). Vulva 10.80-15.85 (13.32). Egg $0.07 \times 0.07$. The ultrastructure shows a cephalic collar with cuticle edges directed forward, three long lips (two ventrolateral and one dorsal) intercalated by three triangular interlabia (Figures 1a, b). The morphological analysis confirmed the identification of $C$. pelagicum.

Five samples were used for genetic studies, but only three sequences suitable for analysis were obtained and deposited on

Table 1. List of species from Genbank, used for comparison in phylogenetic analysis and alignments.

\begin{tabular}{lll}
\hline \multicolumn{1}{c}{ Species } & GenBank accession number & \multicolumn{1}{c}{ Reference } \\
\hline Contracaecum pelagicum & EF122210 & Mattiucci et al. 2008 Syst. Parasitol. 69 (2): 101-121 \\
Contracaecum pelagicum & EF535568 & Mattiucci et al. 2008 Syst. Parasitol. 69 (2): 101-121 \\
Contracaecum pelagicum & EF535569 & Mattiucci et al. 2008 Syst. Parasitol. 69 (2): 101-121 \\
Contracaecum multipapillatum & AF179910 & Nadler and Hudspeth 2000 J. Parasitol. 86 (2): 380-393 \\
Contracaecum micropapillatum & EU852350 & Mattiucci et al. 2010 Syst. Parasitol. 75 (3): 207-224 \\
Contracaecum microcepahulum & EF513519 & Mattiucci et al. 2008 Syst. Parasitol. 69 (2): 101-121 \\
Contracaecum chubutensis & HQ328504 & Garbin et al. 2011 J. Parasitol. 97 (3): 476-492 \\
Contracaecum septentrionale & EF513513 & Mattiucci et al. 2008 Syst. Parasitol. 69 (2): 101-121 \\
Contracaecum rudolphii & EF122201 & Mattiucci et al. 2008 Syst. Parasitol. 69 (2): 101-121 \\
Contracaecum rudolphii & EF513502 & Mattiucci et al. 2008 Syst. Parasitol. 69 (2): 101-121 \\
Sulcascaris sulcata & HQ328505 & Garbin et al. 2011 J. Parasitol. 97 (3): 476-492 \\
\hline
\end{tabular}



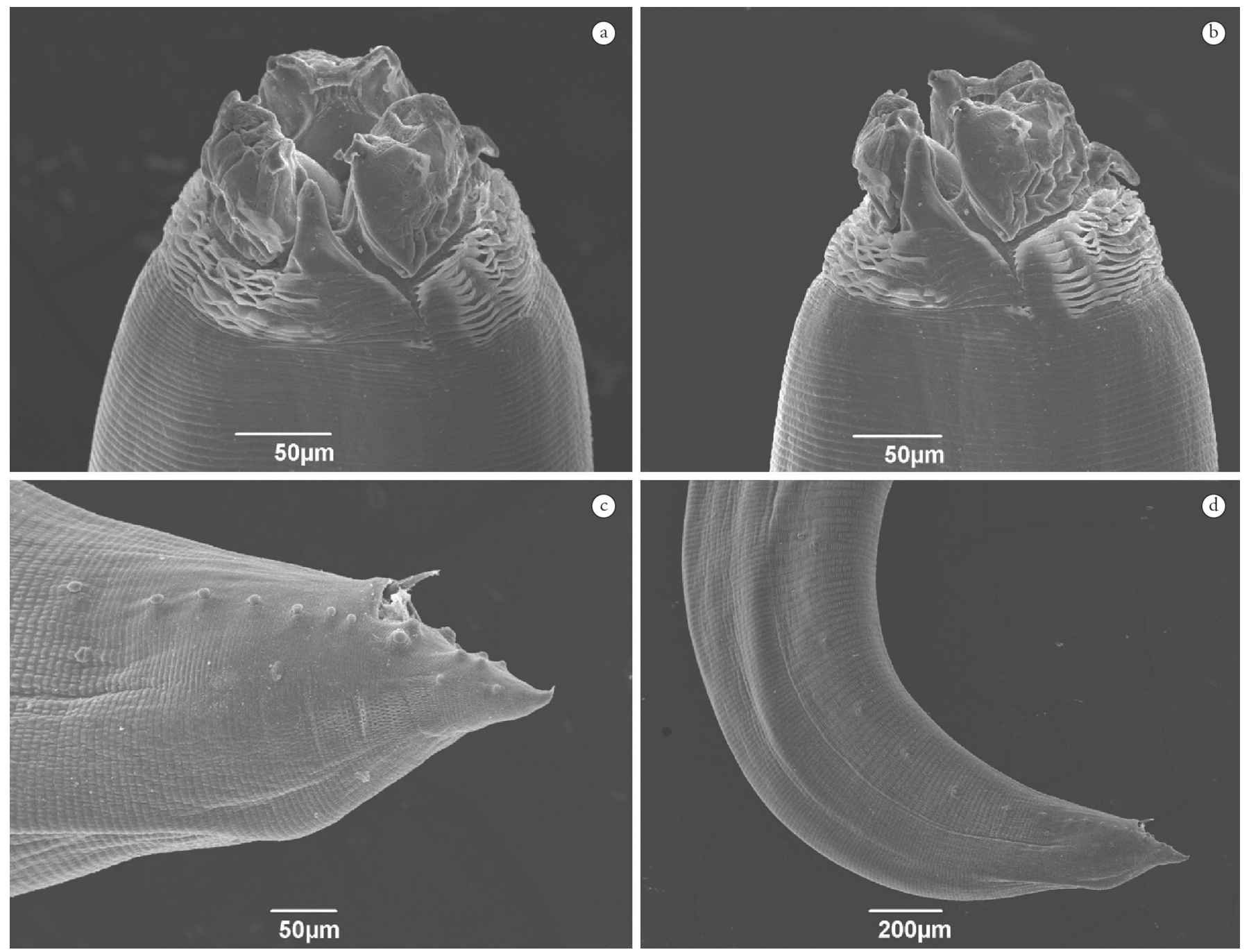

Figure 1. Scanning electron microscopy of Contracaecum pelagicum from Spheniscus magellanicus. a, b - Detail of anterior end, with conspicuous head collar, lips and interlabia. c - Male caudal end with detail of the pre and post-cloacal papillae, cloaca and spicule tip. $\mathrm{d}$ - General view of posterior end of male with distribution of pre and post-cloacal papillae.

GenBank under the accession numbers KC435447, KC435448 and KC435449. These sequences, one with 472 and two with 536 bp, aligned with $C$. pelagicum reference sequence, accession number EF535568 from GenBank with 99\% of similarity; with C. pelagicum accession numbers EF122210 and EF535569, presented 98\% of similarity. The sequences were AT rich with frequencies of $71.1 \%$, $58.8 \%$ and $63.8 \%$ in first, second and third positions of codons, respectively. Only transitions were observed in relation to other C. pelagicum, with a greater rate of T/C substitutions (Table 2). The majority of substitutions occurred in the first position of codons in potentially silent sites. The phylogenetic tree, constructed with the sequences from these studies and the Contracaecum reference sequences from birds, showed strong statistical support for the C. pelagicum branch (Figure 2).

\section{Discussion}

The measurements are in accordance with the data from literature, although the parasites found are much larger than previous descriptions from the same host (SANTOS, 1984; GARBIN et al.,
Table 2. Maximum composite likelihood estimate of the pattern of nucleotide substitution among Contracaecum pelagicum. The table shows the probability of substitution from one base (row) to another (column). Transitional substitutions are shown in bold and transversional substitutions are shown in italics.

\begin{tabular}{ccccc}
\hline \% & A & T & C & G \\
\hline A & - & 0.05 & 0.02 & $\mathbf{1 6 . 2 1}$ \\
T & 0.03 & - & $\mathbf{1 5 . 4 9}$ & 0.03 \\
C & 0.03 & $\mathbf{5 1 . 9}$ & - & 0.03 \\
G & $\mathbf{1 6 . 1 5}$ & 0.05 & 0.02 & - \\
\hline
\end{tabular}

$\%$ - percentage.

2007). Other morphological features such as number of papillae, length and shape of spicules in males, were similar to the ones previously described for C. pelagicum (LENT; FREITAS, 1948; SANTOS, 1984; FAGERHOLM et al., 1996; GARBIN et al., 2007), thus confirming the morphological diagnosis.

The mtDNA cox-2 fragments showed little variation among sites of C. pelagicum. The intraspecific variability of $1-2 \%$ found is in accordance with literature data for Nematodes 


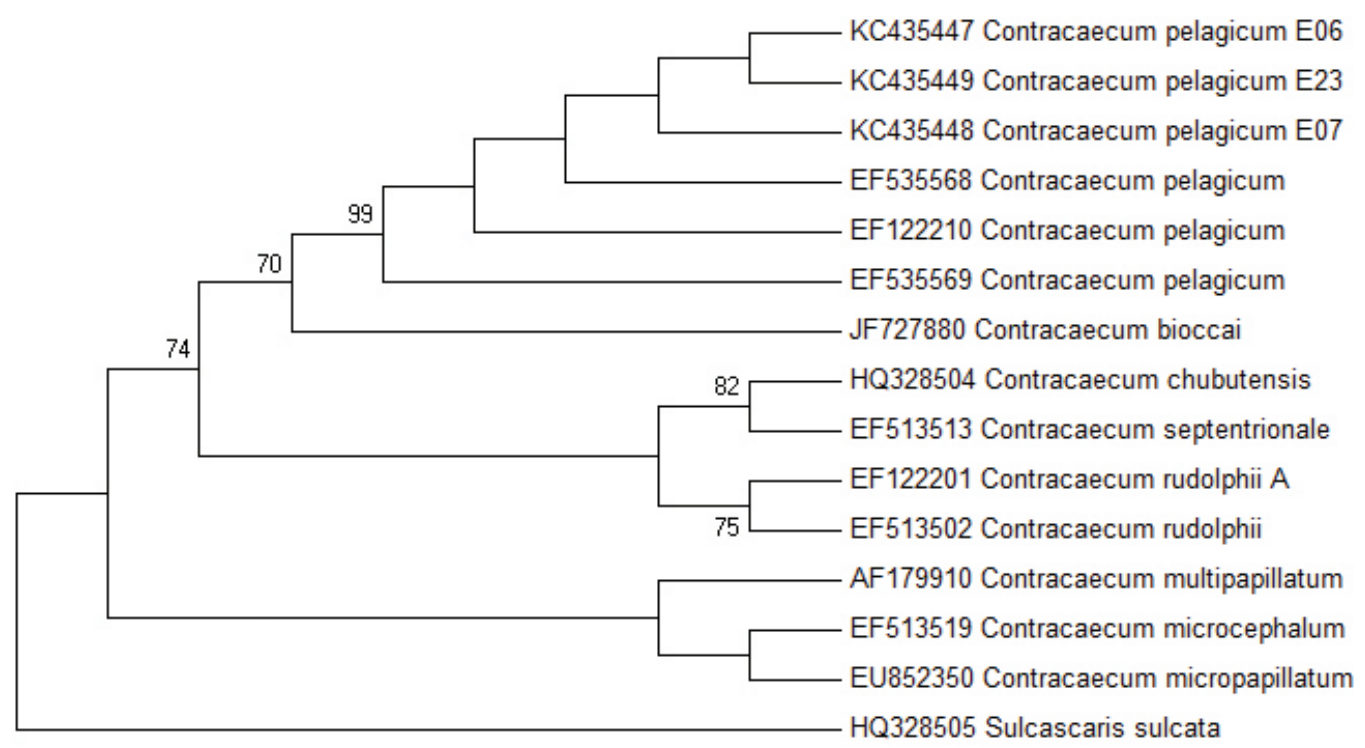

Figure 2. Maximum likelihood reconstruction among Contracaecum pelagicum sequences obtained in this study (E06, E23, E07) and sequences of Contracaecum species from fish eating birds obtained on GenBank, with tree inferred from mtDNA cox-2 data. The numbers on the tree branches represent the percentage of bootstrap resampling. Sulcascaris sulcata was used as an out group.

(THOMAS; WILSON, 1991; GARBIN et al., 2013). In the last 20 years, genetic analysis has been used as an important tool in the identification of sibling species, as well as larval stages of Contracaecum (NASCETTI et al., 1993; ORECCHIA et al., 1994; MATTIUCCI et al., 2002; LI et al., 2005; GARBIN et al., 2013). The small intraspecific variation and the greater interspecific variation found in this study, show how the mtDNA cox- 2 region can be a valuable tool for the identification of species in the genus.

The AT rich composition found has already been reported in literature for Nematode mtDNA cox-2 region (THOMAS; WILSON, 1991; NADLER; HUDSPETH, 2000; JEX et al., 2008). Mattiucci et al. (2008) and Garbin et al. (2013) found values of AT bases frequencies that were very similar to the ones found in this $C$. pelagicum study.

The conducted phylogenetic analysis showed a close relationship between $C$. pelagicum specimens and C. bioccai, which formed a strong statistically supported branch. This close relationship between the two species has been already reported in other studies (GARBIN et al., 2013).

Although there were already C. pelagicum sequences deposited on GenBank, the addition of new data is important to strengthen the reliability of GenBank as a tool for rapid species' identification, and a database for genetic studies. The new sequences deposited on GenBank provide new data for further studies of these parasites that may well be present in marine fishes along the Brazilian coast.

\section{Conclusion}

This is the first genetic characterization of Contracaecum pelagicum from Spheniscus magellanicus penguins in Brazil.

\section{Acknowledgments}

The authors are indebted to RioZoo foundation for the donation of parasites. The study was financially supported by Fundação Carlos Chagas Filho de Amparo à Pesquisa no Rio de Janeiro (FAPERJBIOTA), Conselho Nacional de Desenvolvimento Científico e Tecnológico (CNPq) -PROEP, Coordenação de Aperfeiçoamento de Pessoal de Ensino Superior (CAPES PROCAD-NF, Parasitologia Básica) and Fundação Oswaldo Cruz.

\section{References}

Altschul SF, Gish W, Miller W, Myers EW, Lipman DJ. Basic local alignment search tool. J Mol Biol 1990; 215(3): 403-410. PMid:2231712.

Anderson RC. Nematode parasites of vertebrates: Their development and transmission. Wallingford: CABI Publishing; 2000. 672 p. http://dx.doi. org/10.1079/9780851994215.0000

Borges JN, Cunha LFG, Santos HLC, Monteiro-Neto C, Santos CP. Morphological and Molecular Diagnosis of Anisakid Nematode Larvae from Cutlassfish (Trichiurus lepturus) off the Coast of Rio de Janeiro, Brazil. PLoS One 2012; 7(7): e40447. PMid:22792329 PMCid:PMC3392247. http://dx.doi.org/10.1371/journal.pone.0040447

Campos SDE, Pereira BBN, Siciliano S, Costa CHC, Almosny NRP, Brener B. Contracaecum pelagicum and C. plagiaticium (Nematoda: Anisakidae) infection in Magellanic penguins (Sphenisciformes: Spheniscidae) on the coast of Rio de Janeiro State. Pesq Vet Bras 2013; 33(1): 89-93. http:// dx.doi.org/10.1590/S0100-736X2013000100016

Diaz JI, Cremonte F, Navone GT. Helminths of the Magellanic Penguin, Spheniscus magellanicus (Sphenisciformes), During the Breeding Season in Patagonian Coast, Chubut, Argentina. Comp Parasitol 2010; 77(2): 172177. http://dx.doi.org/10.1654/4441.1

Ederli NB, Oliveira FCR, Monteiro CM, Silveira LS, Rodrigues MLA. Ocorrência de Contracaecum pelagicum Johnston and Mawson, 1942 
(Nematoda, Anisakidae) em pinguim-de-magalhães (Spheniscus magellanicus Forster, 1781) (Aves, Spheniscidae) no litoral do Espírito Santo. Arq Bras Med Vet Zootec 2009; 61(4): 1006-1008. http://dx.doi. org/10.1590/S0102-09352009000400034

Fagerholm HP, Overstreet RM, Humphery-Smith I. Contracaecum magnipapillatum (Nematoda, Ascaridoidea): Resurrection and pathogenic effects of a common parasite from the proventriculus of Anous minutus from the Great Barrier Reef, with a note on C. variegatum. Helminthologia 1996; 33 (4): 195-207.

Felsenstein J. Evolutionary trees from DNA sequences: a maximum likelihood approach. J Mol Evol 1981; 17(6): 368-376. PMid:7288891. http://dx.doi.org/10.1007/BF01734359

Garbin L, Mattiucci S, Paoletti M, González-Acuña D, Nascetti G. Genetic and morphological evidences for the existence of a new species of Contracaecum (Nematoda: Anisakidae) parasite of Phalacrocorax brasilianus (Gmelin) from Chile and its genetic relationships with congeners from fish-eating birds. J Parasitol 2011 97(3): 476-492. PMid:21506861. http://dx.doi.org/10.1645/GE-2450.1

Garbin L, Mattiucci S, Paoletti M, Diaz JI, Nascetti G, Navone GT. Molecular identification and larval morphological description of Contracaecum pelagicum (Nematoda: Anisakidae) from the Anchovy Engraulis anchoita (Engraulidae) and fish-eating birds from the Argentine North Patagonian Sea. Parasitol Int 2013; 62(3): 309-319. PMid:23500719. http://dx.doi.org/10.1016/j.parint.2013.03.001

Garbin L, Navone GT, Diaz JI, Cremonte F. Further study of Contracaecum pelagicum (Nematoda: Anisakidae) in Spheniscus magellanicus (Aves: Spheniscidae) from Argentinean coasts. J Parasitol 2007; 93(1): 143-150. PMid:17436954. http://dx.doi.org/10.1645/GE-875R1.1

García Borboroglu P, Boersma PD, Ruoppolo V, Pinho-Da-SilvaFilho R, Corrado-Adornes A, Conte-Sena D, et al. Magellanic penguin mortality in 2008 along the SW Atlantic coast. Mar Pollut Bull 2010; 60(10): 1652-1657. PMid:20674946. http://dx.doi. org/10.1016/j.marpolbul.2010.07.006

González-Acuña D, Kinsella JM, Lara J, Valenzuela-Dellarossa G. Parásitos gastrointestinales en pingüino de Humboldt (Spheniscus humboldti) y pingüino de Magallanes (Spheniscus magellanicus) en las costas del centro y centro sur de Chile. Parasitol Latinoam 2008; 63: 58-63.

Jex AR, Waeschenbach A, Littlewood DTJ, Hu M, Gasser RB. The mitochondrial Genome of Toxocara canis. PLoS Negl Trop Dis 2008; 2(8): e273. PMid:18682828 PMCid:PMC2483351. http://dx.doi. org/10.1371/journal.pntd.0000273

Lent H, Freitas JFT. Uma coleção de nematódeos, parasitos de vertebrados, do Museu de História Natural de Montevideo. Mem Inst Oswaldo Cruz 1948; 46(1): 1-71. http://dx.doi.org/10.1590/S007402761948000100001

Li AX, D’Amelio S, Paggi L, He F, Gasser RB, Lun Z, et al. Genetic evidence for the existence of sibling species within Contracaecum rudolphii (Hartwich, 1964) and the validity of Contracaecum septentrionale (Kreis, 1955) (Nematoda: Anisakidae). Parasitol Res 2005; 96(6): 361 366. PMid:15928905. http://dx.doi.org/10.1007/s00436-005-1366-y

Mann A. Fauna parasitaria en el pingüino de Humboldt (Spheniscus humboldti), en la zona central de Chile. Santiago: Memoria Fac. Cs Veterinarias y Pecuarias, U. Chile; 1992. 67 p.

Mattiucci S, Paoletti M, Solorzano AC, Nascetti G. Contracaecum gibsoni n. sp. and C. overstreeti n. sp. (Nematoda: Anisakidae) from the Dalmatian pelican Pelecanus crispus (L.) in Greek waters: genetic and morphological evidence. Syst Parasitol 2010 Mar; 75(3): 207-24. Available from: http://www.ncbi.nlm.nih.gov/pubmed/20157795.

Mattiucci S, Paoletti M, Olivero-Verbel J, Baldiris R, Arroyo-Salgado B, Garbin L, et al. Contracaecum bioccai n. sp. from the brown pelican Pelecanus occidentalis (L.) in Colombia (Nematoda: Anisakidae): morphology, molecular evidence and its genetic relationship with congeners from fish-eating birds. Syst Parasitol 2008; 69(2): 101-121. PMid:18038198. http://dx.doi.org/10.1007/s11230-007-9116-4

Mattiucci S, Turchetto M, Brigantini F, Nascetti G. On the occurrence of the sibling species of Contracaecum rudolphii complex (Nematoda: Anisakidae) in cormorants (Phalacrocorax carbo sinensis) from Venetian and Caorle lagoons: Genetic markers and ecological studies. Parassitologia 2002; 44 (Suppl 1): 105.

Nadler AS, Hudspeth DSS. Ribosomal DNA and phylogeny of the Ascaridoidea (Nemata: Secernentea): implications for morphological evolution and classification. Mol Phylogenet Evol 2000; 10(2): 221-236. PMid:9878233. http://dx.doi.org/10.1006/mpev.1998.0514

Nascetti G, Cianchi R, Mattiucci S, D’Amelio S, Orecchia P, Paggi L et al. Three sibling species within Contracaecum osculatum (Nematoda, Ascaridida, Ascaridoidea) from the Atlantic Arcticboreal region: Reproductive isolation and host preferences. Int $J$ Parasitol 1993; 23(1): 105-120. http://dx.doi.org/10.1016/00207519(93)90103-6

Orecchia P, Mattiucci S, D’Amelio S, Paggi L, Plotz J, Cianchi R, et al. Two new members in the Contracaecum osculatum complex (Nematoda, Ascaridoidea) from the Antarctic. Int J Parasitol 1994; 24(3): 367-377. http://dx.doi.org/10.1016/0020-7519(94)90084-1

Santos CP. Um nematódeo parasito do pinguim Spheniscus magellanicus (Forster) (Ascaridoidea, Anisakidae). Mem Inst Oswaldo Cruz 1984; 79(2): 233-237. PMid:6543564. http://dx.doi.org/10.1590/ S0074-02761984000200010

Posada D. jModelTest: Phylogenetic model averaging. Mol Biol Evol 2008; 25(7): 1253-1256. PMid:18397919. http://dx.doi. org $/ 10.1093 / \mathrm{molbev} / \mathrm{msn} 083$

Prado MIBM, Santos-Lopes AR, Silva RJ. Helminthfauna of Magellanic penguin (Spheniscus magellanicus Foster 1781) proceeding from Ilha Comprida, south coast, state of São Paulo, Brazil. Neotrop Helminthol 2011; 5(1): 50-55.

Rezende GC, Baldassin P, Gallo H, Silva RJ. Ecological aspects of helminth fauna of Magellanic penguins, Spheniscus magellanicus (aves: Spheniscidae), from the Northern Coast of the State of São Paulo, Brazil. BrazJ Biol 2013; 73(1): 61-66. PMid:23644789. http://dx.doi. org/10.1590/S1519-69842013000100008

Serafini PP, Gomes ALM, Maranho A, Fernandes A, Mader A, Altiere BL, et al. Projeto Nacional de Monitoramento de Pinguim-de-Magalhães (Spheniscus magellanicus). Brasília: CEMAVE (ICMBio); 2010. 36 p. Available from: http://intranet.cemave.net/downloads/projeto_ pinguins/cartilha_projeto_nacional_pinguins_miolo.pdf.

Silva RJ, Raso TF, Faria PJ, Campos FP. Occurrence of Contracaecum pelagicum Johnston and Mawson 1942 (Nematoda, Anisakidae) in Sula leucogaster Boddaert, 1783 (Pelecaniformes, Sulidae). Arq Bras Med Vet Zootec 2005; 57(4): 565-567. http://dx.doi.org/10.1590/S010209352005000400023

Tamura K, Peterson D, Peterson N, Stecher G, Nei M, Kumar S. MEGA 5: Molecular evolutionary genetics analysis using maximum likelihood, evolutionary distance, and maximum parsimony methods. Mol Biol 
Evol2011; 28(10): 2731-2739. PMid:21546353 PMCid:PMC3203626. http://dx.doi.org/10.1093/molbev/msr121

Thomas, WK, Wilson, AC. Mode and tempo of molecular evolution in the nematode Caenorhabditis: Cytochrome oxidase II and calmodulin sequences. Genetics 1991; 128(2): 269-279. PMid:1649066.

Thompson JD, Higgins DG, Gibson TJ. CLUSTAL W: improving the sensitivity of progressive multiple sequence alignment through sequence weighting, position-specific gap penalties and weight matrix choice. Nucleic Acids Res 1994; 22(22): 4673-4680. PMid:7984417 PMCid:PMC308517. http://dx.doi.org/10.1093/nar/22.22.4673

Yáñez F, Fernández Í, Campos VV, Mansilla M, Valenzuela A, González $\mathrm{H}$, et al. First pathological report of parasitic gastric ulceration in Humboldt penguin (Spheniscus humboldti) along the coast of southcentral Chile. Lat Am J Aquat Res 2012; 40(2): 448-452. http://dx.doi. org/10.3856/vol40-issue2-fulltext-20 